ENTREPRENEURSHIP AND SUSTAINABILITY ISSUES

ISSN 2345-0282 (online) http://jssidoi.org/jesi/

2021 Volume 8 Number 3 (March)

http://doi.org/10.9770/jesi.2021.8.3(32)

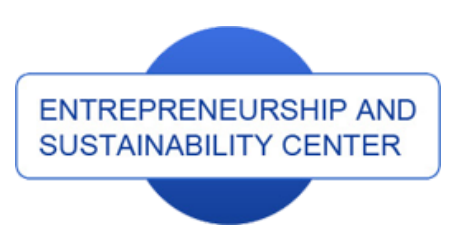

Publisher

$\underline{\text { http://jssidoi.org/esc/home }}$
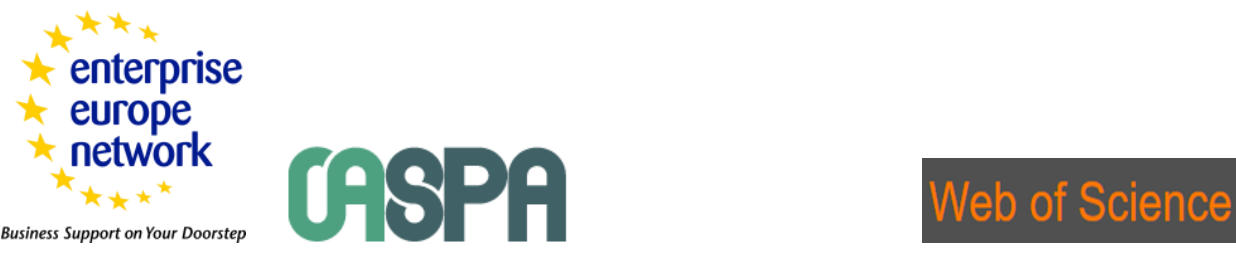

1) Clarivate

Analytics

\title{
MANAGING THE INSTITUTIONAL ENVIRONMENT AND IMPACT ON THE COMPETITIVENESS
} OF TRANSITIONAL ECONOMIES

\author{
Marinko Škare 1, Sanja Radolović ${ }^{2}$, Manuela Tvaronavičiené ${ }^{3,4}$ \\ 1,2 Juraj Dobrila University of Pula, Zagrebačka 30, 52100 Pula, Croatia \\ ${ }^{3}$ Vilnius Gediminas Technical University (Vilnius Tech), Saulètekio 11, LT-10223, Vilnius, Lithuania \\ ${ }^{4}$ General Jonas Zemaitis Military Academy of Lithuania, Silo 5 A, LT-10322, Vilnius, Lithuania \\ E-mails: ${ }^{1}$ mskare@unipu.hr ; ${ }^{2}$ sanja.radolovic@unipu.hr
}

Received 18 September 2020; accepted 28 January 2020; published 30 March 2021

\begin{abstract}
The main unsolved issue in the qualitative research of the "new" institutional economics in the area of the institutional impact on economic growth is how productive institutions occur, i.e., which variables explicitly "stand" behind the institutional "infrastructure" impact on economic growth. The research presents the postulates of the "new" institutional economics, claiming a connection between the institutional structure and the movement of economic growth. Furthermore, the impact of institutional quality on economic growth was analyzed on examples of individual national economies. The comparative method of the assessment based on six criteria: voice and accountability, political stability, government effectiveness, regulatory quality, the rule of law and control of corruption, and the comparison of the GDP per capita of the same as one of the most significant economic indicators, tested the primary hypothesis (H1) in this work: institutions are the fundamental determinant of the long-term success in economy, and the importance of government effectiveness is seen through economic growth, especially long-term growth. The conducted research showed a high level of correlation between institutions' success and the gross domestic product with indications of equal returns per ratio and the fact that the advancement of institutional quality, indirectly through GDP, can lead to the growth of the relative significance of economies.
\end{abstract}

Keywords: institutional economics; quality of institutions; GDP per capita; economic growth

Reference to this paper should be made as follows: Škare, M., Radolović, S., Tvaronavičiené, M. 2021. Managing the institutional environment and impact on the competitiveness of transitional economies. Entrepreneurship and Sustainability Issues, 8(3), 504-526. http://doi.org/10.9770/jesi.2021.8.3(32)

JEL Classifications: C33, DO2, O13, O43

\section{Introduction}

The effect of institutions, their "quality" and capacity on the level of economic growth is the research object of institutional economics, and in the last twenty years of the "new" institutional economics as well, and the theoretical postulates and cognitions which rose from the theoretical and empirical research of the same will be 


\section{ENTREPRENEURSHIP AND SUSTAINABILITY ISSUES}

ISSN 2345-0282 (online) http://jssidoi.org/jesi/

2021 Volume 8 Number 3 (March)

http://doi.org/10.9770/jesi.2021.8.3(32)

presented and analyzed. According to institutional economics, institutions have an essential role in increasing society's functionality, especially economic effectiveness (Vasconcelos, 2021; Lincényi \& Č́rsky, 2021). They are the constituent part of the social capital as the critical factor of economic growth and economic success (Trofimov, 2017; Iacobuta et al., 2019; Mazzanti et al., 2020).

The core of the "new" institutional economics research is the emergence of institutions and their comparative effectiveness and impact on economic growth, economic behavior, success, and division problems. The theoretical and empirical research of the NIE affected the regulatory, macroeconomic, and other public policies.

Central and Eastern European transition countries are one more example of the influence of the institutional development on economic growth, and the question of why certain transition countries had developed faster than others when all went through a similar process of reforms (stabilization of the economy, market liberalization, and privatization) comes as reasonable.

This paper will present the postulates of the "new" institutional economics and the qualitative and empirical research inside it, claiming a link between the institutional structure and the economic growth movement. Furthermore, examples of individual national economies, emphasizing transition countries show the impact of institutional infrastructure on economic growth analysis. The comparative method of the assessment of government effectiveness based on six criteria: voice and accountability, political stability, government effectiveness, regulatory quality, the rule of law and control of corruption, and the comparison of the GDP per capita of the same as one of the most significant economic indicators, tested the primary hypothesis $\left(\mathrm{H}_{1}\right)$ in this work: institutions are the fundamental determinant of the long-term success in economy, and the importance of government effectiveness is seen through economic growth, especially long-term growth.

Literature in the field of institutional economics is vast but there is a gap concerning the institutions' role in economic growth for transitional economies. Institutional transition process in former planned economies largerly differs across ex-socialist countries. The nature of the transitional process, specifically, institutional transitional process dynamics, nature and its impact on competitiveness and growth is missing in the literature. This paper addresses the gap by studying the transition process of the institutional environment for selected transitional economies. Empirical results obtained from the panel vector autoregression estimation later compares to the institutional environment change in advanced economies. This study addresses the issue of institutional environment efficiency impact on economy competitiveness and economic growth in the long run. Empirical results support the thesis that the institutional environment is a significant driver of a country's competitiveness and growth.

Study results prove that government effectiveness' is a key competitiveness factor in an economy. GDP dynamics is not essential for building institutional efficiency (no Granger causality). Voice and accountability as an institutional factor have a limited impact on the country's competitiveness. Freedom of thought and government accountability is vital for a level of competitiveness but not essential. Political stability is significant for the level of competitiveness. Regulatory quality is essential as an institutional factor for competitiveness but not that determinant as government effectiveness and political stability. The rule of law is also crucial for the country's competitiveness, but we find the same long-run relationship as for the regulatory quality. Thus, the rule of law is necessary but not a sufficient condition for competitiveness. Corruption control is a pre-requisite to achieve and increase the level of competitiveness. We can see that after government effectiveness and political stability, corruption control is at the top level of competitiveness determinants. The dummy variable as a proxy for the financial crisis of 2008, as we expected, had a significant impact on the competitiveness across the panel. We can see financial crisis (and financial cycles) significantly negatively impact a country's level of competitiveness. 


\section{ENTREPRENEURSHIP AND SUSTAINABILITY ISSUES}

ISSN 2345-0282 (online) http://jssidoi.org/jesi/

2021 Volume 8 Number 3 (March)

http://doi.org/10.9770/jesi.2021.8.3(32)

\section{Literature review}

In the last twenty years, the scientific and professional literature has been dealing with the incorporation of the institutional impact and institutional structure in economic growth theories, and economic policies and the adaptation to economic movements are strongly dependent on institutional construction (North, 1990; 2003; Myhrman \& Weingast, 1994; Coase, 1998; Torsten Persson, 2001; Powell, 2003; Acemoglu, 2004).

In the broader sense, institutions are formal and informal rules that determine human interrelations (North, 1990). In a narrower sense, institutions are organizational units, procedures, and the regulatory framework (Williamson, 2000). The primary division differentiates exogenous institutions (external, given) and endogenous institutions (internal) to the economic system (Williamson, 2000; Jutting, 2003).

North (1994) divides institutions according to the level of formality to "informal" and "formal" and divides the "formal" ones further on into constitution, statutes, common law, regulative and other state decisions and regulations, political system: structure of power, civil rights, economic structure: inheritance rights, contracts, the coercion system: legislation, police; the author divides informal institutions to traditions, customs, moral values, religious beliefs and other behavioral norms acquired during a time, the prevailing fears and attitudes of the community toward the world, the knowledge collected from the past and the prevailing number of values, the common inheritance (culture) and the informal coercion system: being expelled from the community, criticism, loss of respect.

Moreover, North claims that both types of institutions are present in all countries, but the informal ones are more prominent in "poorer" countries because formal institutions are weekly developed or do not exist. He emphasizes that institutions determine "the rules of the game" in economic, political, and social interactions, as well as "social "organizations (2003). The influence of institutions on transnational multinational firms' strategies has increased enormously. The wide range of studies on the impact of institutions on international policy were covered in the review. In recent international strategy research, it has achieved a much better overall understanding of multinational firms' activities (Xu et al., 2021). The results of (Wu et al., 2019) suggest while it is important for emerging-market governments to develop preferred strategies that encourage their domestic companies to participate actively in global competition, it is also crucial for them to significantly improve the quality of policies that can provide institutional support for these companies to internationalize in various foreign markets and provide innovation advantages.

According to Kasper and Streit (1998), institutions create stimulating structures for individuals and organizations' behaviors and coordinate their activities. Although institutions have to provide predictable and coherent rules, what is also necessary are institutional changes and adaptations to social preferences, technologies, political and socio-economic structures, and external factors. It is also essential to differentiate the institutional environment, a set of fundamental political, social, and legal rules from the institutional organization (agreement among economic units about collaboration and competition). Innovations have an essential role in determining the country's competitiveness in international markets (Awang et al., 2019). Del Olmo-García et al., (2020) indicate a negative relationship between the quality of formal institutions, the entrepreneurial culture, social norms, and efficiency in the markets for goods and services to entrepreneurship failure rate. A positive relationship is shown with respect to high status assigned to successful entrepreneurs.

Institutional economics developed at the turn of the $19^{\text {th }}$ to the $20^{\text {th }}$ century. There are the "old" institutional economics and the "new" institutional economics (Hodgson, 2003). The new institutional economics (NIE), whose leading representatives are North and Williamson, developed around the middle seventies of the $20^{\text {th }}$ 


\section{ENTREPRENEURSHIP AND SUSTAINABILITY ISSUES}

ISSN 2345-0282 (online) http://jssidoi.org/jesi/

2021 Volume 8 Number 3 (March)

http://doi.org/10.9770/jesi.2021.8.3(32)

century to answer the prevailing, neoclassical, and liberal economic thought. Nadeem et al., (2020) study indicate that participation in gross value chains positively affects GDP per capita, and this effect is greater when participation is facilitated by an institution. This data suggests that the inclusion of domestic institutions in strong gross value chains can greatly enhance a country's economic growth.

At the beginning of the 1970s, Douglas Cecil North (1971) developed institutions' theory to modify the neoclassical theoretical model. However, North distanced himself more and more from the neoclassical economic theory and significantly modified the whole approach in the research of the long-term economic growth in the USA and Europe and the analysis of the role and significance of institutions. In that way, he became the founder of NIE. There is a consensus among researchers that poor institutions greatly hinder progress; however, it is widely recognized that this idea is of little use without explanations on how they can be improved and made to self-sustain a "good equilibrium" (Blažys, 2020).

NIE theoreticians consider neoclassical theory as an inadequate tool for the analysis and determination of policies that would stimulate the growth and development since in the neoclassical analysis, it is usually assumed that transactions cost nothing, that information is at free disposal, and that countries are benevolent. NIE thus relies upon the contribution given by Ronald Coase (1937, 1960), who showed that market use has its actors for a price, and "when transactions cost, institutions are important" (North, 1990). Sun et al., (2020) examine how social legitimacy and economic efficiency are associated with corporate philanthropy (CPG). (CPG) is viewed as a cost factor necessary to gain power, and as a resource to achieve efficiency. The paper suggests that state ownership increases the positive effect of infrastructure investment on (CPG) but decreases the positive effect of human capital on (CPG).

NIE's core belief is that institutions are also crucial for economic success and are, therefore, susceptible to economic analysis. In contrast, economic history and development's central task is to consider the evolution of political and economic institutions that form the economic environment stimulating increased productivity (North, 1991). Godlewska and Morawska (2018) found that the size of the territory or the level of debt did not affect the behaviour of local and regional formal institutions (LGU) in their support for the development of entrepreneurship, while the geographical location of the LGU had no influence. The value of supporting entrepreneurship was the way the company was run, the type of company and the number of companies in the area to which the LGU is subject.

According to North (1999), there are three characteristic weaknesses of neoclassicism: first, there are no institutions; second, the assumptions about the acting parties' behavior are inadequate; third, there is no consideration of time. Moreover, North claims, "institutions and technology interact. One without the other cannot lead to economic growth."

Field states that while in the standard neoclassical theory exogenous variables encompass preferences, stocks of factors, technologies, and institutions, NIE attempts to make the latter endogenous to the first three (Field, 1981).

Institutions, as North claims (1997), fundamentally determine how society and economy work. Institutions are the social rules of the game - limitations created by people that shape their interactions. They give a structure to stimuli in exchange, whether political, social, or economic. Institutions responsible for banking regulation and supervision must focus their attention on promoting good corporate governance practices in banking institutions and on providing an appropriate legal and institutional framework to give stability and confidence to the banking system, which is crucial for the proper functioning of the economy as a whole (Arias et al., 2020).

The essence of NIE is the attempt to incorporate the theory of institutions into economics. What is left behind is instrumental rationality - the assumption of neoclassical economics, which made it a theory without institutions. 


\section{ENTREPRENEURSHIP AND SUSTAINABILITY ISSUES}

ISSN 2345-0282 (online) http://jssidoi.org/jesi/

2021 Volume 8 Number 3 (March)

http://doi.org/10.9770/jesi.2021.8.3(32)

As an interdisciplinary economic thought direction, NIE combines economics as a science, law, theory of organization, political sciences, sociology, and anthropology to explain social, political, and economic institutions. At the same time, the transaction costs represent the key to understanding the economy's success (Ahrens, 2002).

NIE "challenges" the neoclassical economic theory and its assumptions about the perfect information and rationality. This recognizes the potential advantages of institutions to solve the consequences of imperfect information and limited rationality. Moreover, it introduces the games' theory, where individuals are not thinking about maximizing their benefit. However, opportunistic, i.e., they try to achieve their interests based on deception, where institutions' role is in decreasing insecurity, giving a structure to everyday life. Simultaneously, institutional limitations include actions forbidden to individuals and define circumstances in which individuals can take specific actions.

Campos and Coricelli (2002) claim that transition countries' growth relates to the GDP per capita's short-term dynamics. Most researchers of growth in transition countries used as a dependent variable the average of the real GDP growth rate during 15 and more years.

Moers (1999) concluded that the broader contribution to the improvement of institutions is higher in transition countries, while Campos (2000) says that the rule of law is the most critical element of public administration quality for the growth of transition countries.

The assessment (Kornai, 2006:3-4) about the significant features of transformation which occurred in the period after the breakup of the former socialist system is relevant:

1. The changes follow the main directions of Western civilization's development: in the economic sphere in the capitalist economic system and politics in a democracy.

2. A complete transformation occurred, which was parallel in all spheres: in economics, in the political structure, in the world of political ideology, in the legal system, and the social stratification.

3. The transformation was not violent.

4. The transformation process occurred in peaceful circumstances; it was not preceded by war.

La Porta (1999, p. 225) claims that in the transition, some political theories about the development of institutions got confirmed: those in power shape institutions to remain in power and direct their resources toward themselves.

Some authors claim that poor public administration is a characteristic of countries with a low level of real GDP per capita (Hall \& Jones, 1999; Kaufmann \& Kraay, 2002; Acemoglu et al., 2004), whereas Glaser et al. (2004) claim growth can be initiated without massive institutional changes, but good institutions are necessary for maintaining long-term growth rates.

To assess the "quality" of institutions, some authors use their empirical research indicators of the base "Doing business - measuring business regulations" of the World Bank. It collects data about good management as part of the set of data about doing business. They can be classified as objective measurements of economic institutions because they express the real costs of resources while doing business, like the time or money spent on administrative proceedings. The ten indicators forming this set of data are:

a) Initiation of business - the average number of procedures an entrepreneur has to deal with to start a business activity, the number of days and height of costs necessary to conclude the process, and the lowest amount of capital necessary to initiate a business activity 


\section{ENTREPRENEURSHIP AND SUSTAINABILITY ISSUES}

ISSN 2345-0282 (online) http://jssidoi.org/jesi/

2021 Volume 8 Number 3 (March)

http://doi.org/10.9770/jesi.2021.8.3(32)

b) Release of permits - procedures necessary to do business in the construction industry to build a standard warehouse, as well as the time and costs needed to terminate the procedures

c) Regulation of the labor market - (or employment of workers) a combination of three different circumstances: flexibility and costs of hiring and dismissing employees, and working conditions

d) Registration of assets - procedures, including time and costs, necessary for the transfer of property from the seller to the purchaser in cases when land or business facilities are bought for the need for economic activities

e) Obtaining loans - lessor and lessee's legal rights which facilitate loans, based on the law of bankruptcy and collateral, as well as coverage, quality, and availability of credit information through public and private loan registers

f) Protection of investors - protection of minor shareholders from the abuse of directors linked to company assets, protection of investors and degree of transparency

g) Payment of taxes - corporate income tax which a medium enterprise has to pay in the second business year and efficiency of tax administration, based on the number of payments and time spent to fill in tax forms

h) Cross-border business activities - efficiency of customs and trade transport in a country, as well as the number of documents and days necessary to do the customs import and export procedures

i) Implementation of contracts - number of court proceedings, duration, and expenditures for the execution of a contract by which the efficiency of a court or administrative system for the charge of due debts is measured

j) Termination of business activities - difficulties in "turning off" an economic activity, time and costs included in the proceedings in case of insolvency, as well as the charge rate.

\section{Institutional infrastructure on the example of national economies and economic growth}

Some societies are organized to support the rule of law, support investments in machinery, better technology, and human capital, and facilitate citizens' intensive participation in economic and political life. This means that such societies have "good institutions" ensuring property rights and stimuli for investment and participation in economic life, limitations to elitist, political and other influential groups' actions, i.e., the disabling of profit expropriation and creation of inequalities in the division (of income, goods...), as well as the equalization of possibilities for all the citizens - enabling investments, especially in education, and participation in productive economic activities.

IMF (2018, p. 52) has ranked the United Kingdom and the USA the highest, and Albany and Belarus the lowest when it comes to institutional quality (Figure 1). 


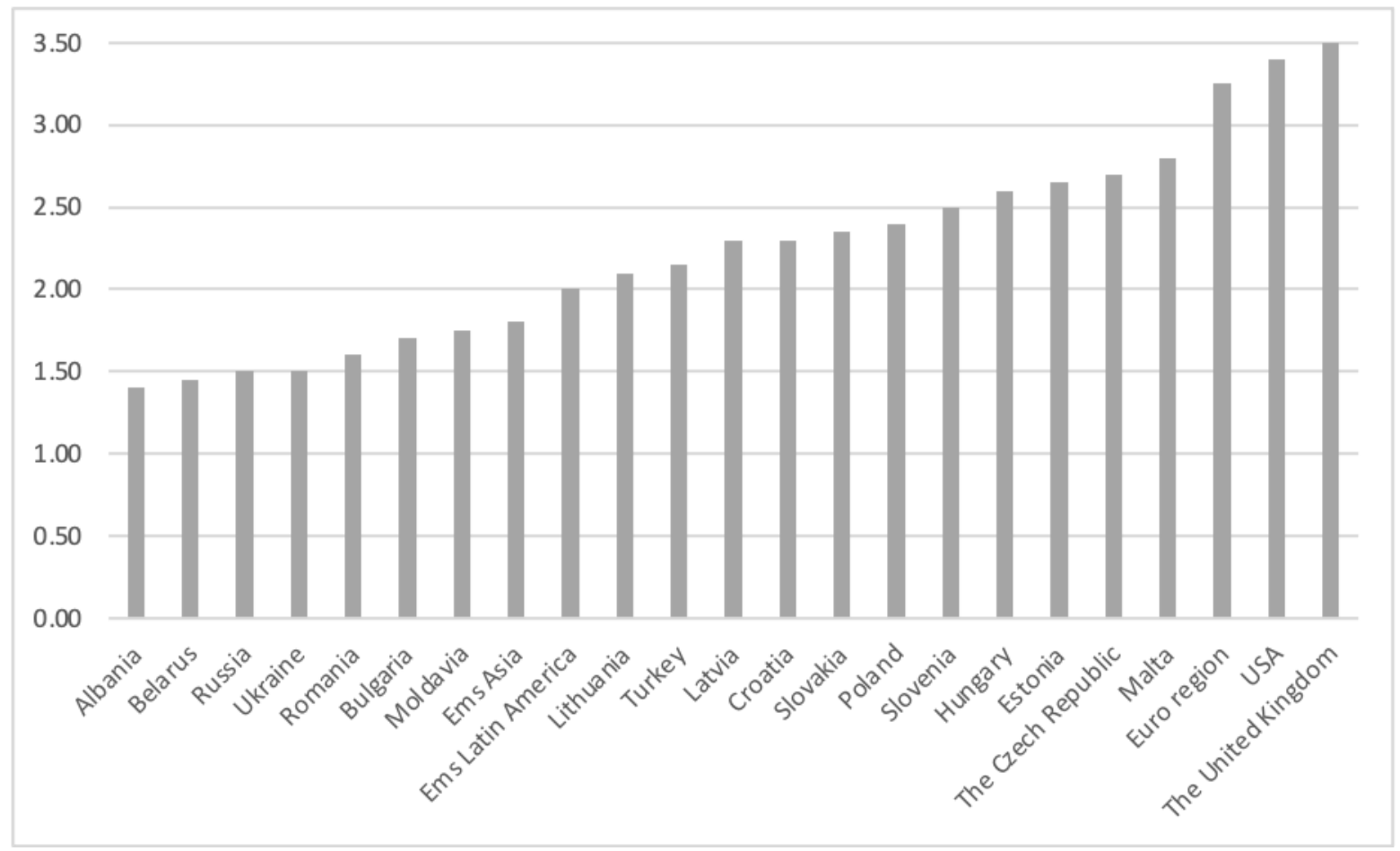

Figure 1. Representation of the institutional quality of individual countries in 2018

Source: IMF Regional Economic Outlook: Europe (2018:52)

One of the "simplest" examples of national economies linked to institutional quality and public administration and narrowly connected to the impact on economic growth and proof of the primary hypothesis is the example of North and South Korea (Figure 2).

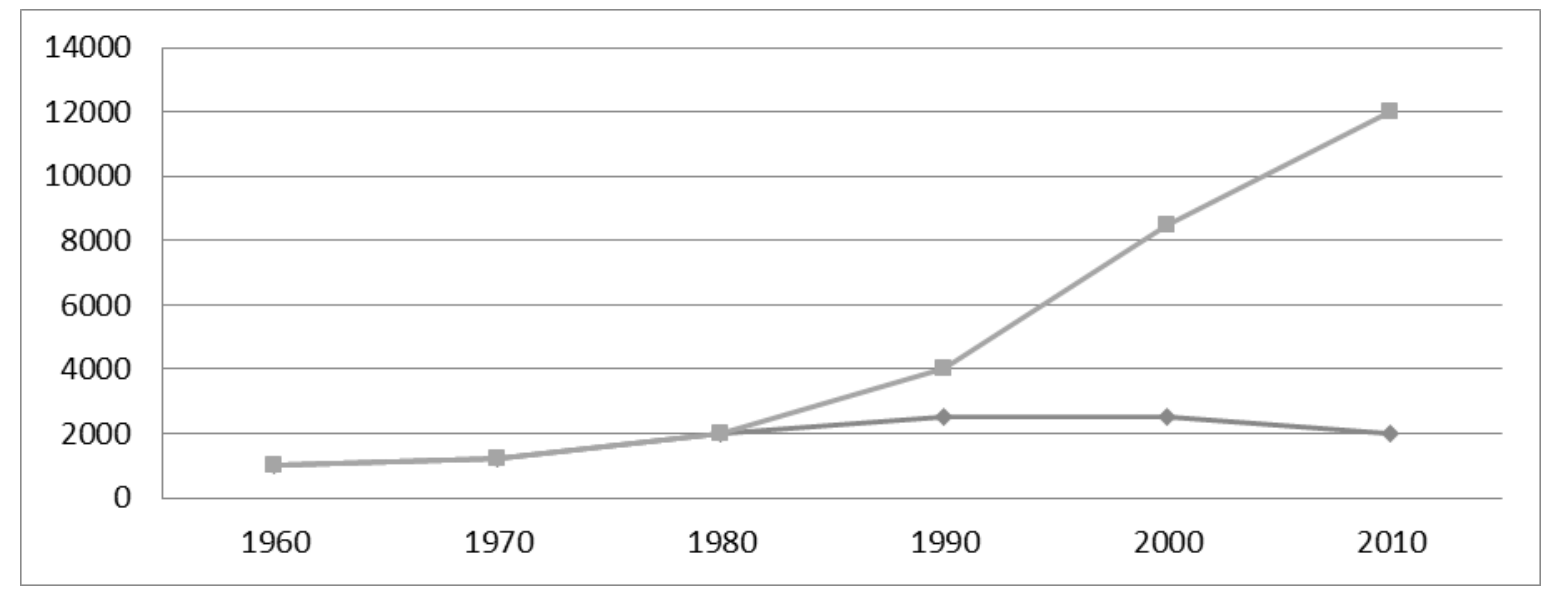

Figure 2. GDP per capita movement in North and South Korea since their "separation."

Source: Authors' calculation 


\section{ENTREPRENEURSHIP AND SUSTAINABILITY ISSUES}

ISSN 2345-0282 (online) http://jssidoi.org/jesi/

2021 Volume 8 Number 3 (March)

http://doi.org/10.9770/jesi.2021.8.3(32)

What followed in Korea was the divergent economic growth so that South Korea became the "Asian miracle," a developed country with GDP per capita of 31,363 \$ (2018), while North Korea lagged behind the substantial economic and social "gap" with a GDP per capita of 583 \$. Institutional differences led to considerable differences in growth and development, and the dysfunctional institutions of the "North" remain unchanged due to the governing political elite's interests.

\subsection{Developmental characteristics of transition countries}

Transition countries represent a particular "case" linked to the research on the link between economic growth impacts. Namely, institutions became part of econometric research of transition countries' growth only at the end of the 1990s. However, any research encompassing transition countries is limited in advance, not only due to the short period for which data are available, but because not all the countries had the same tempo of reform conduction. In this sense, these countries could have different models of growth. Research studies show uncertainty whether the dependent variable of the empirical analysis of economic growth should be the growth rate or its level.

The institutional vacuum that followed the fall of socialism was at the source of economic reforms' success and failure. It showed that there should have existed minimal institutions for developing the market at the beginning of the transitions, limiting unwanted human behaviors and diminished insecurity. The transition brought a set of exogenous shocks that gave greater power to some social groups, and their organizational ability depended on the institutions which were existent at the time.

Transitional changes which started in the area of central and Eastern Europe co-occurred at two levels:

a) an intense process of democratization of those societies by creating an institutional base for a democratic life (political parties, strengthening of the non-governmental sector of institutions), and

b) at the same time, and often present conviction that these general political context changes will internally and externally, almost automatically, form the conditions for efficient market economics.

The European Bank for Reconstruction and Development (EBRD, 2006) identified the problematic areas of transition and stated their institutional solutions:

a) for economic growth, it is necessary:

$>$ to introduce political institutions that support constitutional stability, political and civil freedoms and ensure efficient legislative and executive power, and have to be based on the will expressed by most citizens. In this sense, the establishment of a broad spectrum of institutions is not sufficient - their functioning presupposes a consensus about the fact that they serve for the mutual control of those in power

$>$ to evaluate the contribution in creating income and ensure its fair distribution

$>$ to set the institutional framework which ensures the implementation of contracts and reforms.

b) for the success of companies:

$>$ the institutional framework has to stimulate technological growth, privatization, and creation of new private companies, higher direct foreign investment, quality of the business environment, and competition

c) for the development of the labor market in order to diminish unemployment, it is necessary:

$>$ to introduce new, adequate institutions on the labor market which will increase the employment of laborers

d) the strengthening of the financial sector needs: 


\section{ENTREPRENEURSHIP AND SUSTAINABILITY ISSUES}

ISSN 2345-0282 (online) http://jssidoi.org/jesi/

2021 Volume 8 Number 3 (March)

http://doi.org/10.9770/jesi.2021.8.3(32)

the privatization of the banking sector and large national companies and the consolidation of smaller banks.

\section{Data and methodology}

In the group of transitional countries, one can differentiate between those who became EU members and those who strive to become members. Namely, the starting position of new member states in the EU convergence process is characterized by their economic and political transition systems. The existence of different forms of national or public property, relative isolation from the influence of international competition due to protectionist trade policies and the non-convertibility of national currencies, economic policies directed toward the maintenance of the nominal full employment, and the insufficient incentives for reconstruction aiming at the increase of export and technological development are the standard features of transition EU member states at the beginning of their accession process.

In all countries, the accession process stimulated the bearers of policies, citizens, and business sectors to reach a consensus that it is necessary to conduct a fast institutional transition. For this purpose, the EU offered guidelines in the form of acquis communautaire and the Copenhagen criteria. According to those EU guidelines, the states' governments in the accession process met the membership conditions and acquired credibility to introduce institutional changes.

The institutional model developed in new EU member states was described by Ahrens (2006) as a combination of institutional shock - therapy and new governments' introduction modeled on western countries.

Transitional reforms were the first phase in transforming countries, which, simultaneously with institutional, legal, and organizational changes, created the preconditions for a successful accession to the EU. The fact that new member states have at their disposal institutions, regulations, and market mechanisms identical to those in EU-15 states does not imply that these countries' transition process is complete.

The first consequence of the described reforms' conduction was the "transformation recession," during which transition economies lost up to 60\% of the pre-transition 1989 GDP. The most advanced transition countries, the new EU member states, reached the 1989 DP level only at the end of the nineties. The economic growth rates of new member states, when compared to old EU-15 members, were 2 to 5\% higher, with economies of Baltic countries, Slovakia, Romania, and Bulgaria having the fastest growth. Simultaneously, these were the economies with the worst initial positions since these were small and very closed countries in which reforms ended a few years later than in, for instance, Hungary and Poland. The achieved success is ascribed to the economy's maturity, and readiness to attract significant foreign direct investment (FDI), stimulated fast economic growth.

The fastest move in the available indicators of institutional quality has occurred since the World Bank started to make public the public administration quality indicators globally. Today, they are considered unavoidable aggregate indicators of institutional quality. The indicators of public administration quality of the World Bank are calculated in six areas, namely:

1) Freedom of thought and accountability of public administration (voice and accountability)

2) Political stability

3) Government effectiveness

4) Regulatory quality

5) The rule of law

6) Control of corruption 
These indicators can determine the quality of legislative, administrative, and judicial institutions and compare them to other countries' indicators.

To prove the paper's primary hypothesis, the comparative analysis of the legislative, administrative, and judicial institutions will be used, and it measured by the indicators of government effectiveness published by the World Bank.

To analyze the institutional impact on countries' competitiveness, we use using the panel vector auto-regression model (PVAR) in the reduced form:

$$
z_{i t}=\Gamma_{0}+\Gamma_{1} z_{t-1}+\varepsilon_{t}
$$

following (Abrigo and Love, 2016), we use

with

$\mathrm{Y}_{\mathrm{it}}=(1 \mathrm{x} \mathrm{k})$ vector of dependent variables from table 1

$\mathrm{X}_{\mathrm{it}}=(1 \mathrm{x} l)$ vector of exogenous covariates

$\mathrm{u}_{\mathrm{i}}, \mathrm{e}_{\mathrm{it}}=(1 \times \mathrm{k})$ vectors of dependent variable-specific panel fixed-effects and idiosyncratic errors

$\mathrm{A}_{1}, \mathrm{~A}_{2}, \ldots, \mathrm{Ap}-1, \mathrm{Ap}=$ estimation parameters

matrix $\mathrm{B}(1 \times \mathrm{k})=$ estimation parameters

assumming innovation $\mathrm{E}($ eit $)=0, \mathrm{E}$ (eiteit) $=\Sigma$, and $\mathrm{E}($ eiteis $)=0$ for all $\mathrm{t}>\mathrm{s}$. Following (Abrigo and Love, 2016) we do not demean the panel data before estimation prior to helm transformation.

List of variables in the model:

(ge) = government effectiveness,

$($ via $)=$ voice and accountability,

$(\mathrm{stab})=$ political stability,

$($ reg $)=$ regulatory quality,

$($ rule $)=$ rule of law,

$($ cont $)=$ corruption control,

(cris) = dummy variable for the financial crisis of 2008 effects having value 1 in time of GDP fall and 0 in time of GDP rise.

We use (PVAR) for original data and reports (PSVAR) results with GMM (generalized moment method) in the following section. 


\section{Results}

According to the indicators of government effectiveness published by the World Bank by which the comparative representation of all countries in the world can be obtained, a comparative graphic representation was created in line with the indicators of public administration quality by the World Bank for Austria, Bosnia and Herzegovina, Croatia, France and Poland from 2008 to 2018. These countries are selected because Austria and France are historically economically developed countries, Poland and Croatia as examples of developing countries, and Bosnia and Herzegovina are examples of independence (Figure 3).

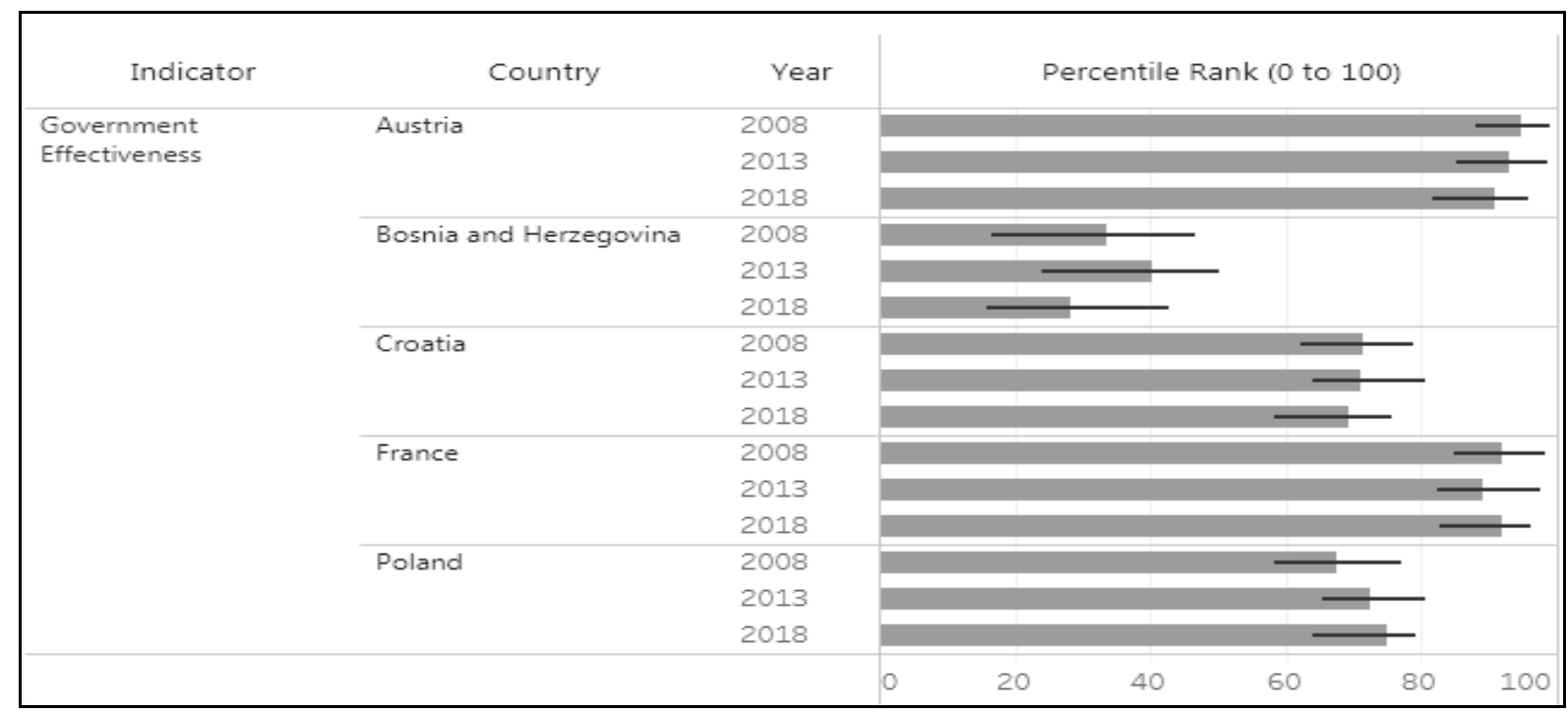

Figure 3. Government effectiveness in chosen countries from 2008 to 2018

Source: Authors' calculation according to data of the World Bank, Governance Indicators (2019), available on http://info.worldbank.org/governance/wgi/index.aspx\#reports

The comparative graphic representation of government effectiveness shows that Croatia as a new EU member state made "small" steps of progress in the governance area from 2008 to 2018, that it is very advanced in comparison to Bosnia and Herzegovina, and that it lags behind Poland only a little, but also that to Austria and France these differences are enormous and extremely visible (Figure 4). 
ENTREPRENEURSHIP AND SUSTAINABILITY ISSUES

ISSN 2345-0282 (online) http://jssidoi.org/jesi/

2021 Volume 8 Number 3 (March)

http://doi.org/10.9770/jesi.2021.8.3(32)

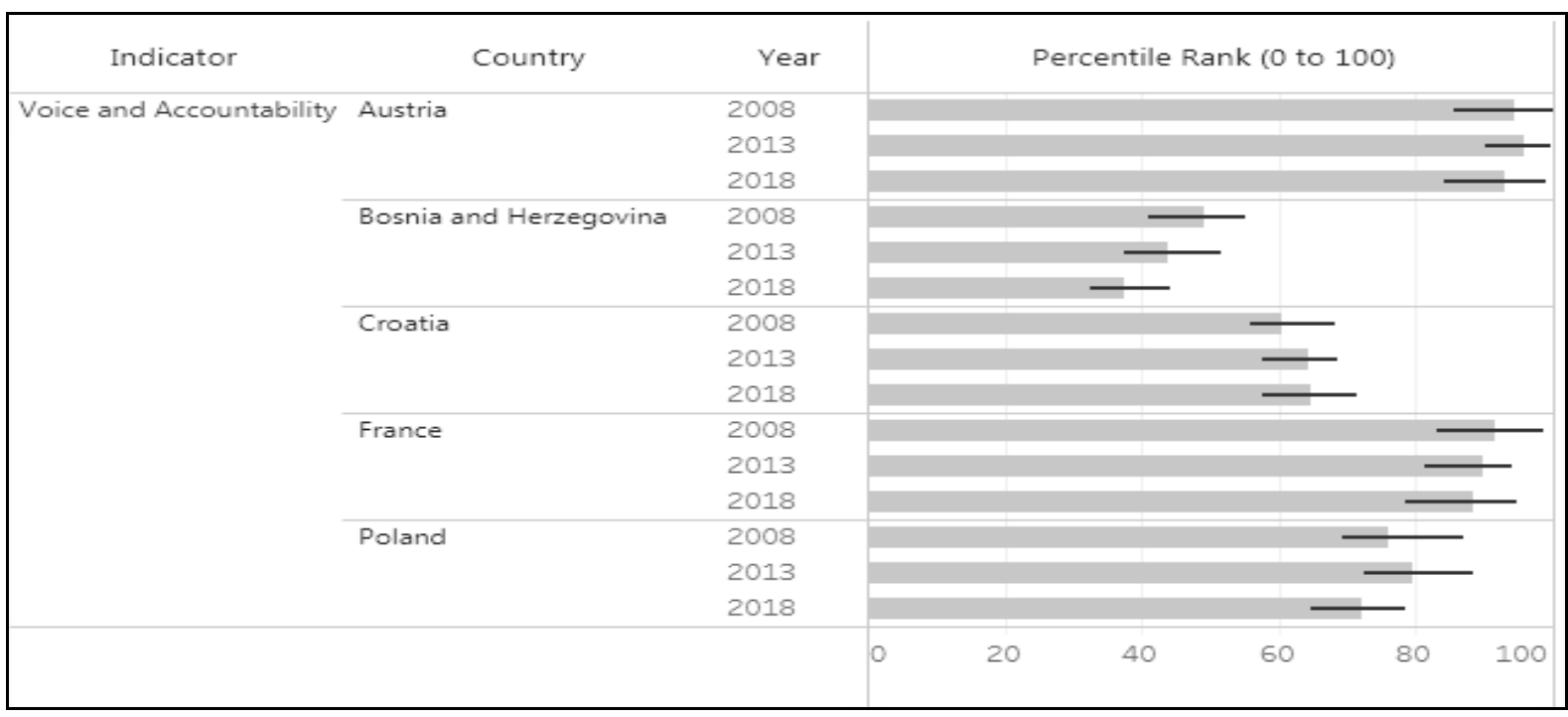

Figure 4. Voice and accountability of the chosen countries

Source: Authors' calculation according to data of the World Bank, Governance Indicators (2019), available on http://info.worldbank.org/governance/wgi/index.aspx\#reports

Figure 4 shows that freedom of thought and government accountability in Austria and France are high. Croatia records minor growth or stagnation in the freedom of thought from 2008 to 2018, but the differences are still expressed. It lags behind Austria, France, and to a lower extent Poland, and is better than Bosnia and Herzegovina only (Figure 5).

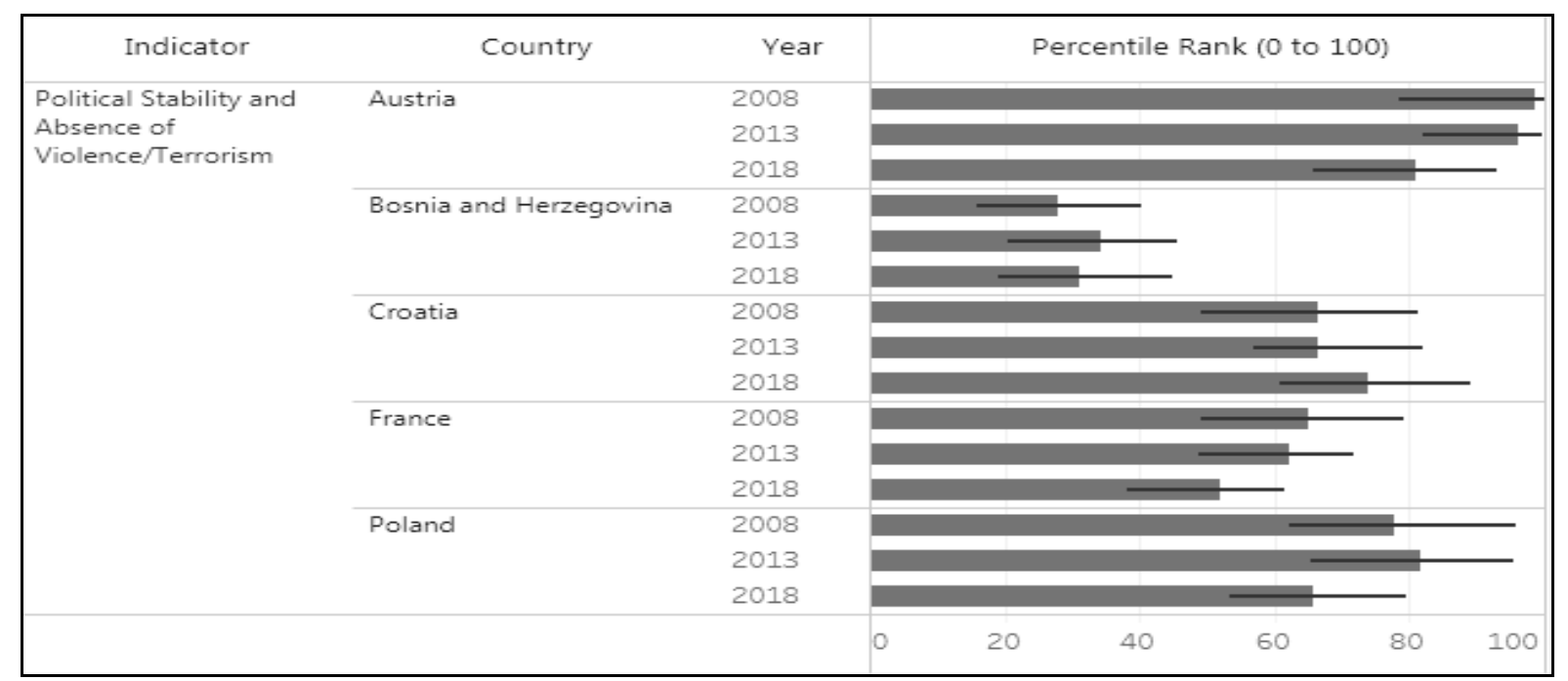

Figure 5. The political stability of chosen countries from 2008 to 2018

Source: Authors' calculation according to data of the World Bank, Governance Indicators (2019), available on http://info.worldbank.org/governance/wgi/index.aspx\#reports 
The political stability chart shows that Austria has the highest level of political stability. Although its political stability has significantly deteriorated in years, it is still ahead of other countries. Croatia has been making advancement in this area for years and is the only country among the analyzed ones with constant growth. In the period 2013 to 2018, a significant advancement could be noticed. The comparison with other countries puts Croatia in a good position, immediately after Austria and Poland. France showed a significant downfall, whereas Bosnia and Herzegovina, although with small steps forward, is still accounted as bad when it comes to political stability and absence of violence (Figure 6).

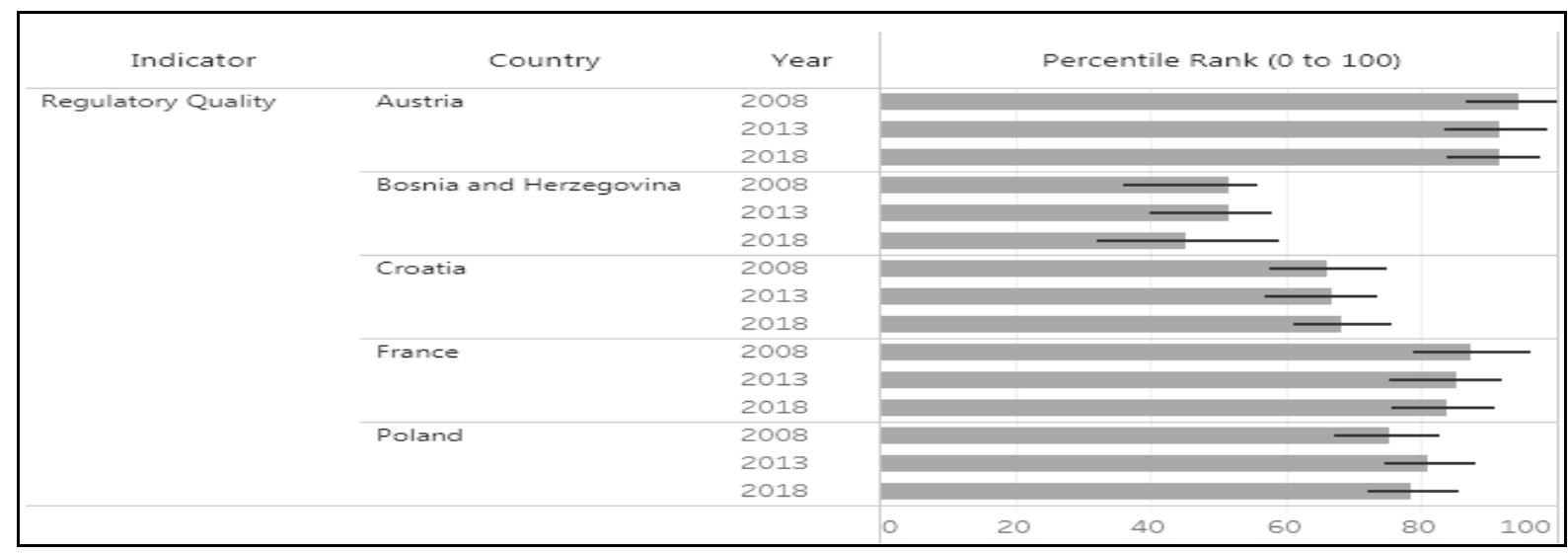

Figure 6. The chosen countries' regulatory quality from 2008 to 2018

Source: Authors' calculation according to data of the World Bank, Governance Indicators (2019), available on http://info.worldbank.org/governance/wgi/index.aspx\#reports

The comparative chart proves that Croatia is making small steps forward regarding the quality of legislation. Besides more significantly lagging behind Austria and somewhat less behind France, Poland is a close second. It is followed by Bosnia and Herzegovina, which shows quite a decline (Figure 7).

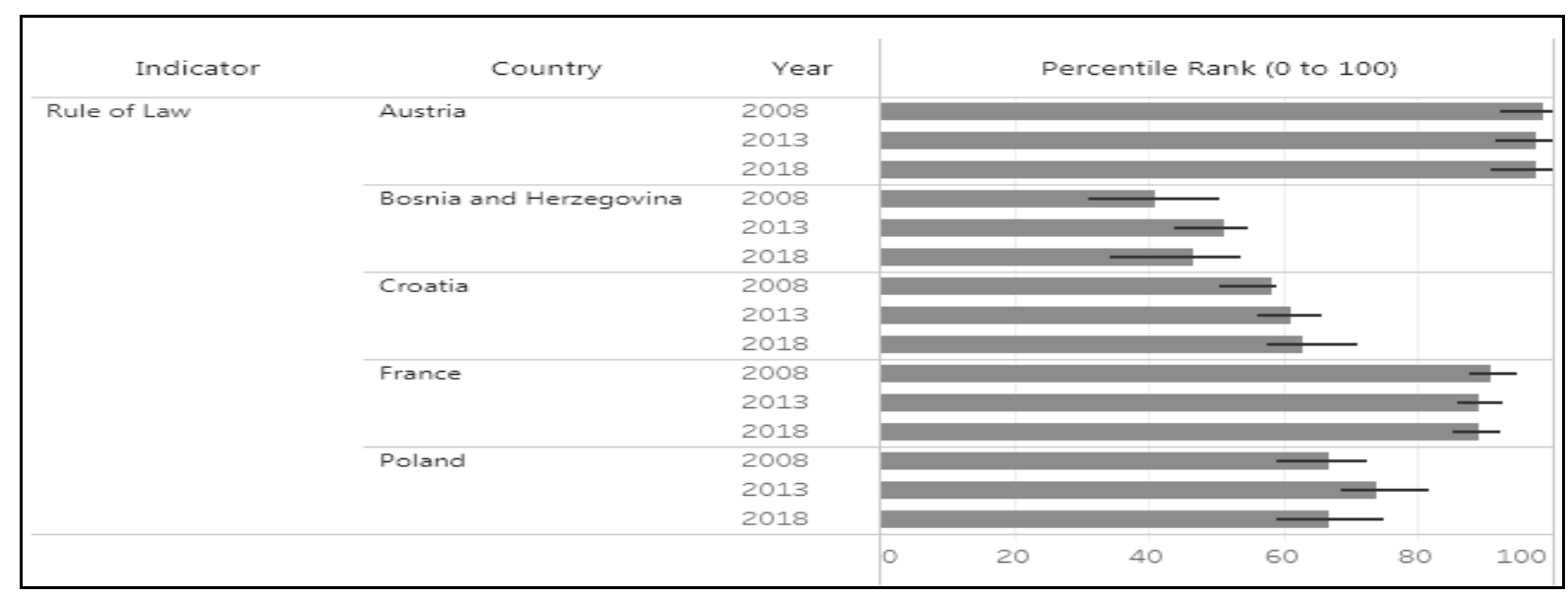

Figure 7. The rule of law in the chosen countries from 2008 to 2018

Source: Authors' calculation according to data of the World Bank, Governance Indicators (2019), available on http://info.worldbank.org/governance/wgi/index.aspx\#reports 
When it comes to the rule of law, Croatia shows a small shift forward from 2008 to 2018, but it still significantly lags behind countries such as Austria and France. It is a close second behind Poland, while Bosnia and Herzegovina are still at the end of the line (Figure 8).

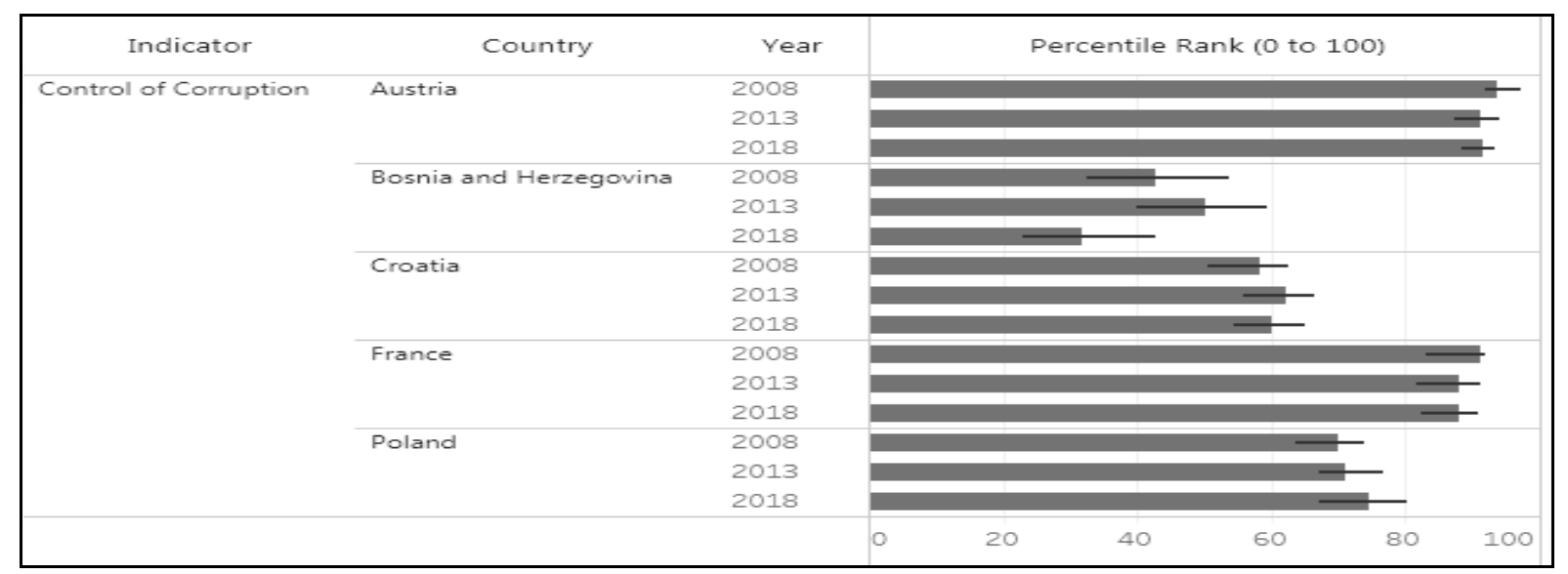

Figure 8. Corruption control in chosen countries from 2008 to 2018

Source: Authors' calculation according to data of the World Bank, Governance Indicators (2019), available on http://info.worldbank.org/governance/wgi/index.aspx\#reports

The chart about corruption control from 2008 to 2018 shows that it is high in Austria and France. In this period, Croatia was a bit oscillating, while Poland recorded a mild growth. In 2018 Bosnia and Herzegovina recorded a severe downfall in corruption control and seriously lagged behind other countries (Figure 9).

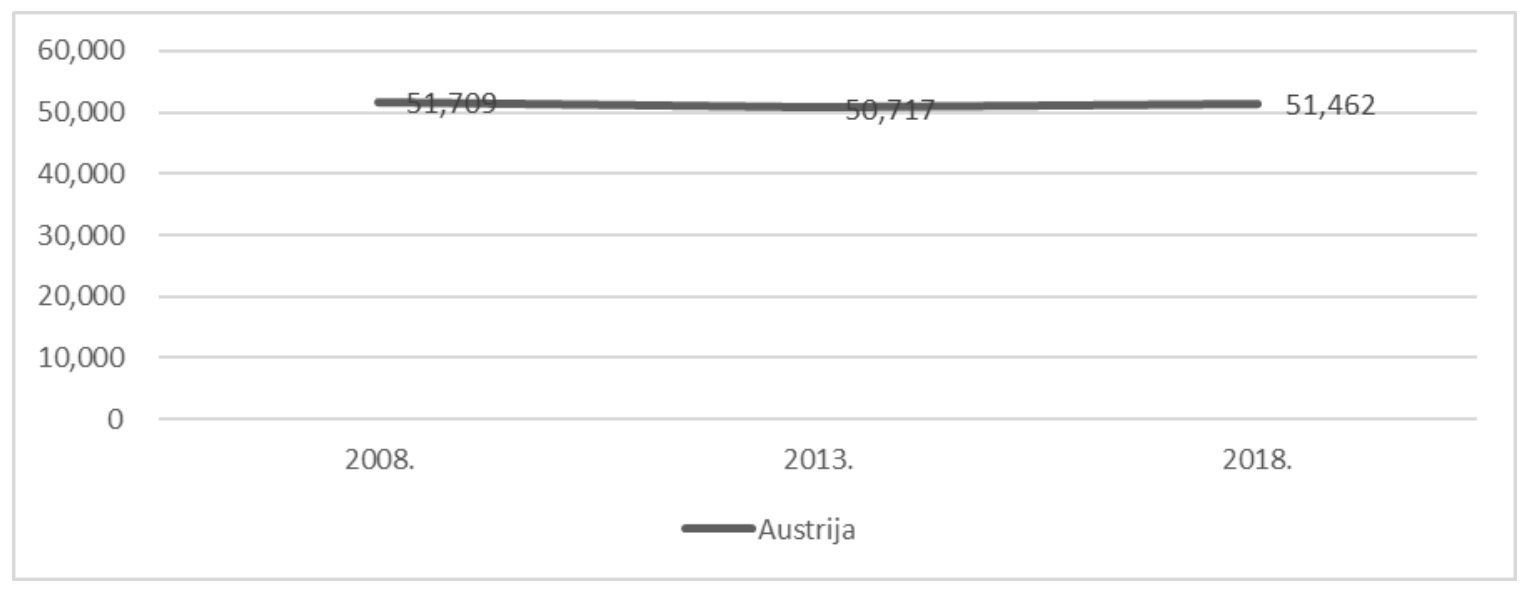

Figure 9. GDP per capita movement in Austria

Source: Authors' calculation according to data of the World Bank, Governance Indicators (2019), available on http://info.worldbank.org/governance/wgi/index.aspx\#reports

In 2008 the GDP per capita in Austria was 51,709 USD, and five years later (2013), it underwent a small decline to 50,717 USD. Economic growth was recorded in 2018 when the GDP per capita equaled 51,462 USD. 


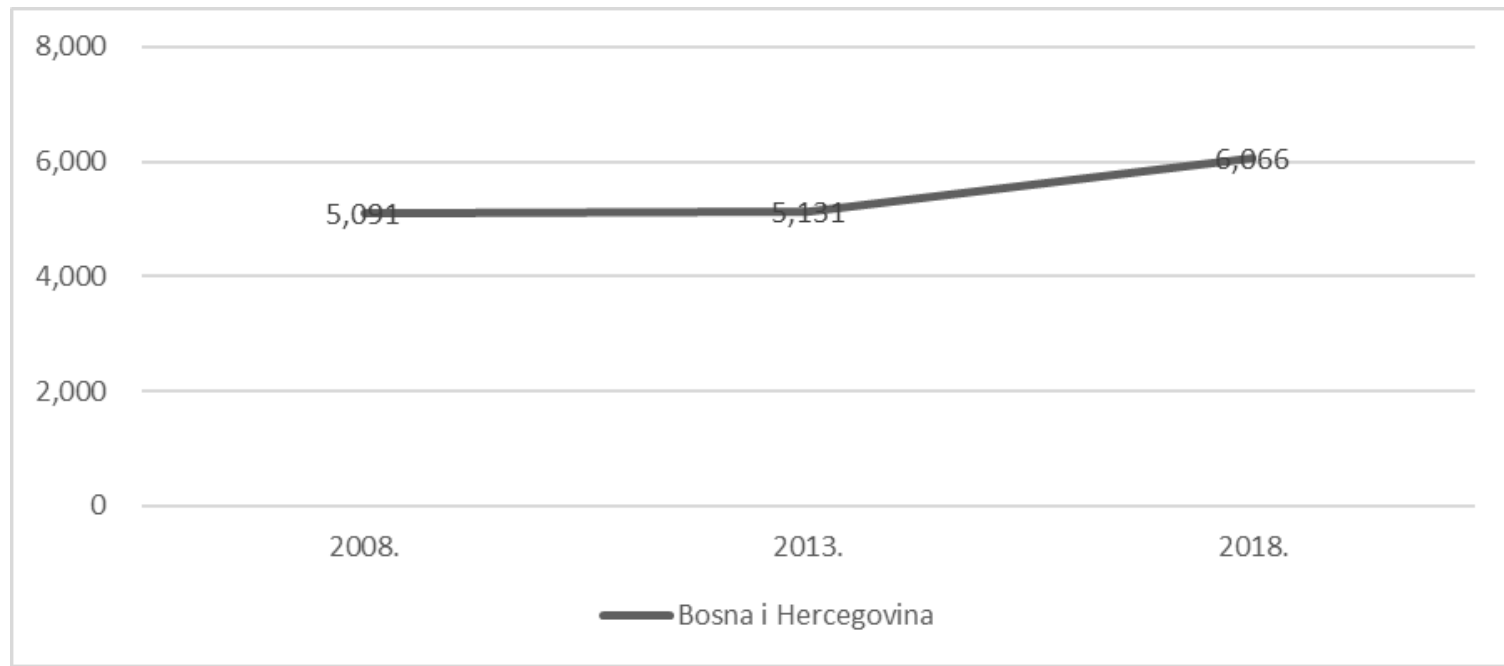

Figure 10. GDP per capita movement in Bosnia and Herzegovina

Source: Authors' calculation according to data of the World Bank, Governance Indicators (2019), available on http://info.worldbank.org/governance/wgi/index.aspx\#reports

According to the World Bank data, in 2008, the BDP in Bosnia and Herzegovina equaled 5,091 USD. In 2013 that number grew to 5,131 USD, and in 2018 the GDP per capita was 6,066 USD. This shows that Bosnia and Herzegovina achieved economic growth (Figure 10).

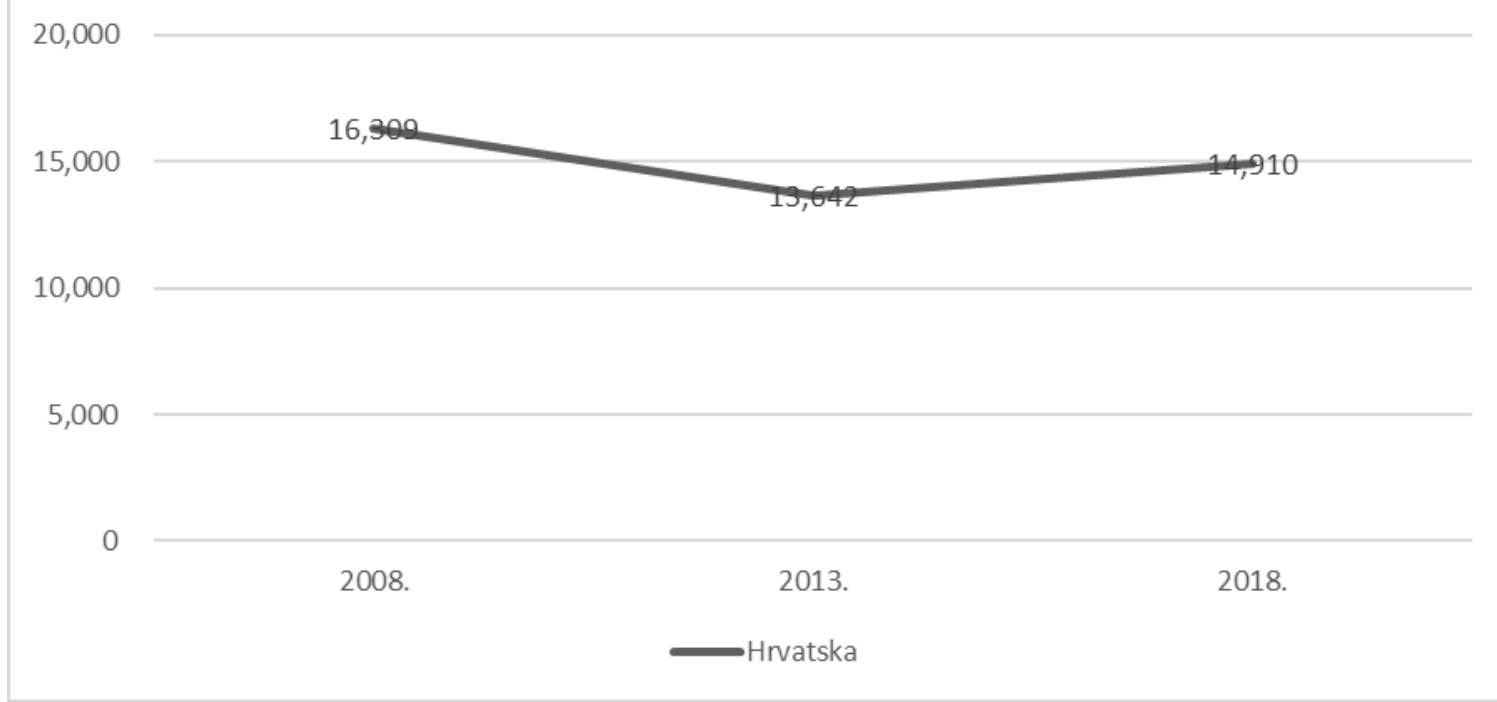

Figure 11. GDP per capita movement in the Republic of Croatia

Source: Authors' calculation according to data of the World Bank, Governance Indicators (2019), available on http://info.worldbank.org/governance/wgi/index.aspx\#reports 
In 2008 the Croatian GDP per capita was 16,309 USD, and after that, in 2013, an economic decline to 13,642 was registered. In 2018 the GDP per capita in Croatia grew to 14,910 USD (Figure 11).

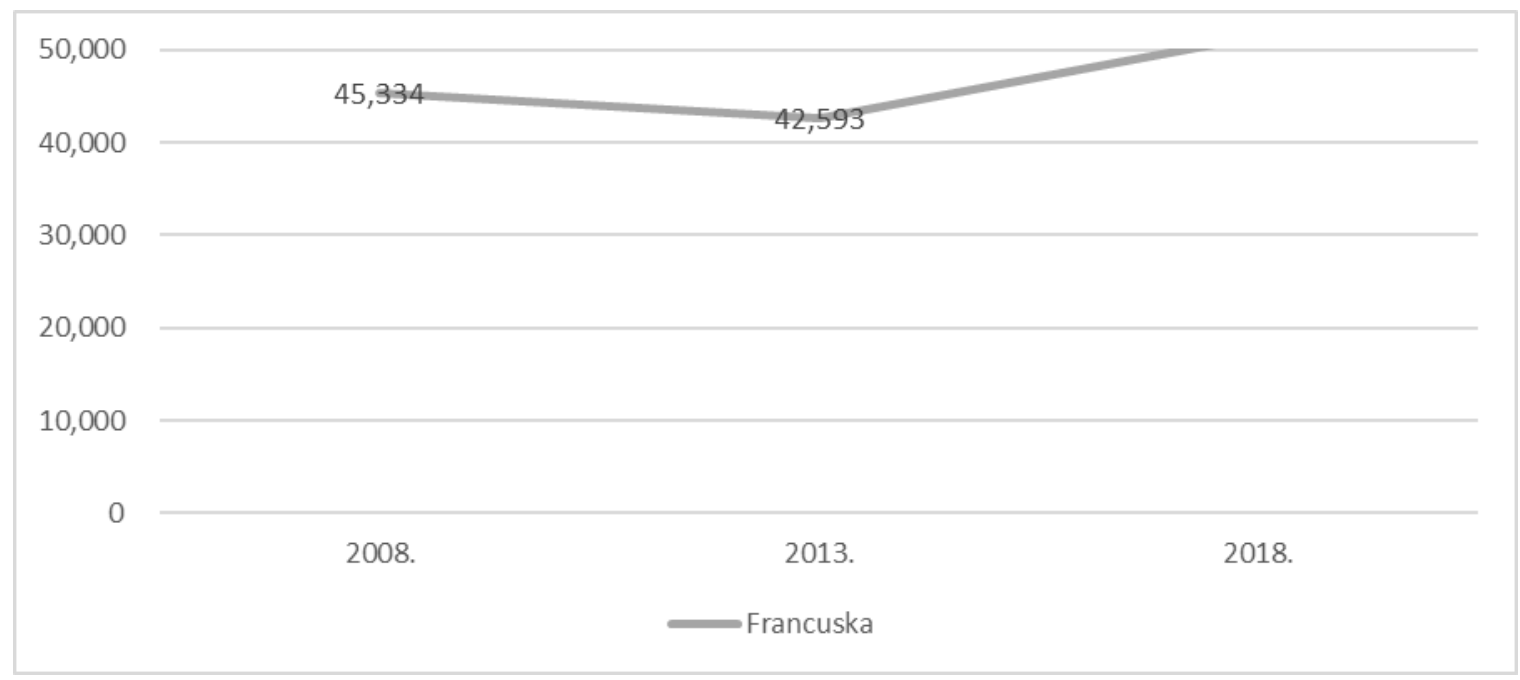

Figure 12. GDP per capita movement in France

Source: Authors' calculation according to data of the World Bank, Governance Indicators (2019), available on http://info.worldbank.org/governance/wgi/index.aspx\#reports

During the years, France has shown an economic decline. In 2008 the GDP per capita equaled 45,334 USD. In 2013, it was 42593 USD, and 2018 continues with a mild decline trend with 41, 464 USD (Figure 12).

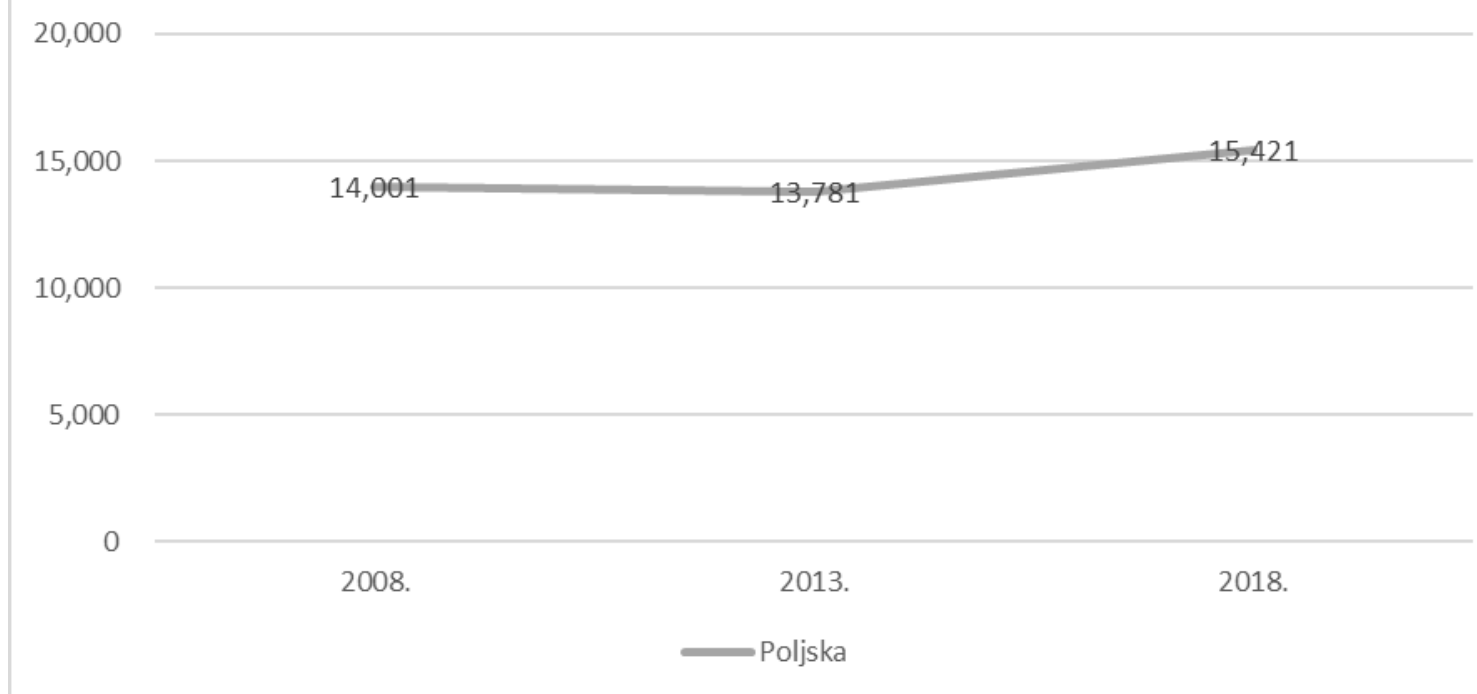

Figure 13. GDP per capita movement in Poland

Source: Authors' calculation according to data of the World Bank, Governance Indicators (2019), available on http://info.worldbank.org/governance/wgi/index.aspx\#reports 
In 2008 the Polish GDP per capita was 14,001 USD. In 2013 this amount decreased to 13,781 USD, followed again by a visible growth in 2018 when the GDP per capita was 15,421 USD (Figure 13).The comparative analysis of the quality of legislative, administrative, and judicial institutions was measured by indicators of government effectiveness published by the World Bank. Comparison of the GDP per capita as an indicator of economic growth confirmed the primary hypothesis. Institutions are the Fundamental Determinant of the LongTerm Success of Economy. Namely, the example of Austria, Bosnia and Herzegovina, France, Croatia, and Poland, which were the comparative analysis object, compared the GDP per capita. It was proved that countries with the highest level of economic growth and GDP per capita are those countries which in the given ten-year period had an enviable level of "successful institutions existence," i.e., Austria and France. Simultaneously, the "golden mean" was filled in by the transition country Poland followed by Croatia, whereas Bosnia and Herzegovina are lagging with substantial economic and institutional discrepancies.

We are showing Granger causality Wald tests for each approximate underlying equation (PVAR) model (Granger 1969). Here we use countries' GDP as a proxy for the level of competitiveness. Results of the (PVAR) Granger causality Wald test we present in table 1.

Table 1. (PVAR) Granger causality Wald test for competitiveness

\begin{tabular}{|c|c|c|c|}
\hline Equation/Excluded & Chi2 & Df & Prob> chi 2 \\
\hline \multicolumn{4}{|l|}{$\operatorname{lgdp}$} \\
\hline ge & 10.328 & 1 & 0.001 \\
\hline $\begin{array}{c}\text { ALL } \\
\text { ge }\end{array}$ & 10.328 & 1 & 0.001 \\
\hline lgdp & 1.069 & 1 & 0.301 \\
\hline ALL & 1.069 & 1 & 0.301 \\
\hline \multicolumn{4}{|l|}{$\operatorname{lgdp}$} \\
\hline via & 1.656 & 1 & 0.198 \\
\hline $\begin{array}{c}\text { ALL } \\
\text { via }\end{array}$ & 1.656 & 1 & 0.198 \\
\hline $\operatorname{lgdp}$ & 1.776 & 1 & 0.183 \\
\hline ALL & 1.776 & 1 & 0.183 \\
\hline \multicolumn{4}{|l|}{$\operatorname{lgdp}$} \\
\hline stab & 4.821 & 1 & 0.028 \\
\hline $\begin{array}{l}\text { ALL } \\
\text { stab }\end{array}$ & 4.821 & 1 & 0.028 \\
\hline $\operatorname{lgdp}$ & 1.225 & 1 & 0.268 \\
\hline ALL & 1.225 & 1 & 0.268 \\
\hline \multicolumn{4}{|l|}{$\operatorname{lgdp}$} \\
\hline reg & 1.483 & 1 & 0.223 \\
\hline $\begin{array}{c}\text { ALL } \\
\text { reg }\end{array}$ & 1.483 & 1 & 0.223 \\
\hline $\operatorname{lgdp}$ & 2.279 & 1 & 0.131 \\
\hline All & 2.279 & 1 & 0.131 \\
\hline \multicolumn{4}{|l|}{$\operatorname{lgdp}$} \\
\hline rule & 1.486 & 1 & 0.223 \\
\hline $\begin{array}{l}\text { ALL } \\
\text { rule }\end{array}$ & 1.486 & 1 & 0.223 \\
\hline $\operatorname{lgdp}$ & 0.236 & 1 & 0.627 \\
\hline ALL & 0.236 & 1 & 0.627 \\
\hline \multicolumn{4}{|l|}{$\operatorname{lgdp}$} \\
\hline cont & 2.789 & 1 & 0.095 \\
\hline ALL & 2.789 & 1 & 0.095 \\
\hline cont & & & \\
\hline $\operatorname{lgdp}$ & 0.357 & 1 & 0.550 \\
\hline ALL & 0.357 & 1 & 0.550 \\
\hline $\operatorname{lgdp}$ & & & \\
\hline
\end{tabular}


ENTREPRENEURSHIP AND SUSTAINABILITY ISSUES

ISSN 2345-0282 (online) http://jssidoi.org/jesi/

2021 Volume 8 Number 3 (March)

http://doi.org/10.9770/jesi.2021.8.3(32)

\begin{tabular}{c|ccc} 
cris & 3.086 & 1 & 0.079 \\
ALL & 3.086 & 1 & 0.079 \\
cris & & & 0.179 \\
lgdp & 1.803 & 1 & 0.179 \\
ALL & 1.803 & 1 & \\
\hline
\end{tabular}

Source: Authors' calculations

The results above show whether the coefficients on the institutional variables appearing on the lgdp equation are jointly zero. The null hypothesis is (excluded variable does not Granger-cause Equation variable), or institutional variables do not Granger-cause country's competitiveness measured by GDP growth.

\section{Discussion}

(PVAR) Granger causality Wald test results in table 1 support the thesis that the institutional environment is a significant driver of a country's competitiveness. Since the panel data series are non-stationary as unit root test results show (not presented here due to space constraint), we use the first differenced variable series to achieve stationarity; we need to run a stable (PVAR) model. First, we test the Granger causality between a country's competitiveness (lgdp) and institutional environment variables using two lags. Test results on ALL show the Granger-causality test results for all lag coefficients. Test results support the hypothesis that institutional factors are essential for competitiveness, but there is a degree of difference between them (some are more important than others).

The first test shows government effectiveness (ge) Granger cause competitiveness (lgdp), and the null hypothesis of no Granger-causality is rejected at a 99\% confidence level. Our results prove that government effectiveness' is a key competitiveness factor in an economy. GDP dynamics is not essential for building institutional efficiency (no Granger causality).

Voice and accountability (via) as an institutional factor have a limited impact on the country's competitiveness. We accept the $\mathrm{H}_{0}$ hypothesis of no Granger causality at the $78 \%$ confidence level. Freedom of thought and government accountability is vital for a level of competitiveness but not essential.

Political stability is significant for the level of competitiveness. We can see that political stability (stab) Granger causes competitiveness at the $95 \%$ confidence level. Political stability significantly affects the macroeconomic conditions having an impact on the level of competitiveness. We find evidence of the positive impact of political stability conditions on the level of competitiveness. The higher the level of political stability, the higher the level of a country's competitiveness.

Regulatory quality (reg) is essential as an institutional factor for competitiveness but not that determinant as government effectiveness and political stability. We can see that (reg) impacts the level of competitiveness (lgdp) at a lower confidence level (89\%).

The rule of law is also crucial for the country's competitiveness, but we find the same long-run relationship as for the regulatory quality. The rule of law does not Granger cause competitiveness at the confidence level higher of $78 \%$. Thus, the rule of law is necessary but not a sufficient condition for competitiveness.

Corruption control is a pre-requisite to achieve and increase the level of competitiveness. We can see that corruption control (cont) Granger causes competitiveness at a 90\% confidence level. We can see that after government effectiveness and political stability, corruption control is at the top level of competitiveness determinants. 


\section{ENTREPRENEURSHIP AND SUSTAINABILITY ISSUES}

ISSN 2345-0282 (online) http://jssidoi.org/jesi/

2021 Volume 8 Number 3 (March)

http://doi.org/10.9770/jesi.2021.8.3(32)

The dummy variable (cris) as a proxy for the financial crisis of 2008, as we expected, had a significant impact on the competitiveness across the panel. We can see that (cris) Granger causes competitiveness at a 93\% confidence level supporting the thesis that financial crisis (and financial cycles) significantly negatively impact a country's level of competitiveness.

Our results support the study results from Rusu and Roman (2018), Djeri et al. (2018), and Radulescu et al. (2019).

\section{Conclusion}

The mentioned empirical research and literature review concluded that the overall results are that "institutions make the difference." However, it remains unsolved whether the given institutions are the source of economic growth or has growth incited by an adequate economic policy led to the formation of new institutions.

By the conducted research of correlation of institutional quality and economic growth, it can be concluded that economic institutions can contribute to a better understanding of the good and bad sides of an economic quality which aims at improving economic success and that institutions can be significant for the global position of an economy.

The research showed a high level of correlation between institutions' success and gross domestic product with indications of equal returns per ratio. The advancement of institutional quality, indirectly through GDP, can lead to the relative significance of economies.

The research limitations are that the indicators of government effectiveness of the World Bank do not reflect certain permanent institutional features. However, the results of a particular country's policies in the former period and specific governance dimensions are measured very widely.

Moreover, it is evident in the research that institutional quality is vital for growth. However, the cognitions about the relative significance of institutions compared to other determinants of growth and development, such as the historical heritage or trade, i.e., the foreign trade exchange, is unclear, representing a recommendation for future research.

\section{References}

Acemoglu, D., Johnson, S. \& Robinson, J. A. (2006). Institutions as a Fundamental Cause of Long-Run Growth. In Aghion, P. and Stephen, D. (eds). Handbook of Economic Growth, North Holland, Amsterdam.

Ahrens, J. \& Meurers, M. (2000). Institutions, Governance, and Economic Performance in Post-Socialist Countries: A Conceptual and Empirical Approach. $4^{\text {th }}$ International Conference "Institutions in Transition," 23 - 24 June, Portorož, Slovenia, pp. $314-317$.

Arias, J., Maquieira, C., \& Jara, M. (2020). Do legal and institutional environments matter for banking system performance?, Economic Research-Ekonomska Istraživanja, 33(1), 2203-2228, https://doi.org/10.1080/1331677X.2019.1666023

Austria Wirtschaftsservice: www.awsg.at

Beck, T. \& Laeven, L. (2005). Institution Building and Growth in Transition Economies. World Bank Policy Research Working Paper, No. 3657.

Blažys, E. (2020). Governance spending fixation as a tool for reform to improve institutions, Economic Research-Ekonomska Istraživanja, 33(1), 934-956, https://doi.org/10.1080/1331677X.2019.1676282 


\section{ENTREPRENEURSHIP AND SUSTAINABILITY ISSUES}

ISSN 2345-0282 (online) http://jssidoi.org/jesi/

2021 Volume 8 Number 3 (March)

http://doi.org/10.9770/jesi.2021.8.3(32)

Campos, N. F. \& Coricelli, F. (2002). Growth in Transition: What We Know, What We Don't, and What We Should. William Davidson Institute Working Paper, No. 470.

Campos, N. F. (2000). Context is Everything: Measuring Institutional Change in Transition Economies. World Bank Working Paper, No. 2269.

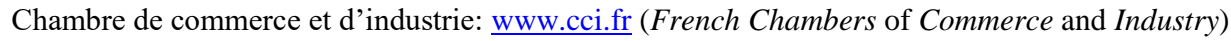

Croatian Bureau of Statistics, www.dzs.hr

del Olmo-García, F., Crecente, F., \& Sarabia, M. (2020). Macroeconomic and institutional drivers of early failure among self-employed entrepreneurs: an analysis of the euro zone, Economic Research-Ekonomska Istraživanja, 33(1), 1830-1848, https://doi.org/10.1080/1331677X.2020.1754268

Duke Economics. (October 19, 2010). Timur Kuran: Institutions and Economic Performance, YouTube. https://www.youtube.com/watch?v=IbAL7s2QgNk

Edison, H. (2003). Testing the Links: How Strong are the Links Between Institutional Quality and Economic Performance?. Finance and Development, (40), 2, 35-37.

Federal Ministry of Finance of Bosnia and Herzegovina, http://www.fmf.gov.ba/

French Ministry for the Economy and Finance: www.economie.gouv.fr

Grossman, G. M. \& Helpman, E. (1991). Innovation and Growth in the Global Economy. Cambridge, Mass. The MIT Press.

Hair Jr., J. F., Black, W. C., Babin, B. J., Anderson, R. E. (2009). Multivariate Data Analysis (7 ${ }^{\text {th }}$ Edition), Prentice Hall.

Hammermann, F., Schweickert, R. (2005). EU Enlargement and Institutional Development: How Far Away Are the EU's Balkan and Black Sea Neighbors?. Kiel Working Paper No. 1261, Kiel Institute for World Economics, November 2005.

Iacobuta, A-O., Mursa, G.C., Mihai, C., Cautisanu, C., \& Cismas, L.M. (2019). Institutions and Sustainable Development: A CrossCountry Analysis. Transformations in Business \& Economics, Vol. 18, No 2A (47A), 628-646.

Kasper, W. \& Streit, M. E. (1998). Institutional Economics. Cheltenham: Edward Elgar.

Kaufmann, D. \& Kraay, A., (2002). Growth Without Governance. World Bank Working Paper, No. 2928.

Knack, S. \& Keefer P. (1995). Institutions and Economic Performance: CrossCountry Tests Using Alternative Institutional Measures. Economics and Politics, 7 (3), 207-227.

Knack, S. (2003). Democracy, Governance and Growth, The University of Michigan Press: Ann Arbor.

Kornai, J. (2006). The Great Transformation of Central Eastern Europe: Success and Disappointment. Croatian Journal of Social Policy, Year 13, No. 3-4, Zagreb, July - December 2006.

La Porta, R. et al. (1999). The Quality of Government. Journal of Law, Economics and Organization, 15 (1), pp. $222-279$. https://doi.org/10.1093/jleo/15.1.222

Lincényi, M., Č́ársky, J. (2021). Research of citizens' behavior in a political campaign in searching for and monitoring political advertising in The Slovak Republic. Insights into Regional Development, 3(1), 29-40. https://doi.org/10.9770/IRD.2021.3.1(2)

Mazzanti, M., Mazzarano, M., Pronti, A., Quatrosi, M. (2020). Fiscal policies, public investments and wellbeing: mapping the evolution of the EU. Insights into Regional Development, 2(4), 725-749. http://doi.org/10.9770/IRD.2020.2.4(1)

Ministry of Finance od the Republic of Poland, http://www.mf.gov.pl/ministerstwo-finansow

Ministry of State Treasury of the Republic of Poland, http://www.msp.gov.pl/portal/en/43/Announcements.html 


\section{ENTREPRENEURSHIP AND SUSTAINABILITY ISSUES}

ISSN 2345-0282 (online) http://jssidoi.org/jesi/

2021 Volume 8 Number 3 (March)

http://doi.org/10.9770/jesi.2021.8.3(32)

Moers, L. (1999). Growth Empirics with Institutional Measures and Its Application to Transition Countries: A Survey. Tinbergen Institute Discussion Papers, No. 98-126/2.

Nadeem, M., Momna Niazi Y.J., Tian, Y., \& Subhan, S. (2020). Paths of economic development: a global evidence for the mediating role of institutions for participation in global value chains, Economic Research-Ekonomska Istraživanja, https://doi.org/10.1080/1331677X.2020.1804426

North, D. C. (1971). Institutional change and Economic Growth, Journal of Economic History, 31, 118 - 125.

North, D. C. (1991). Institutions. Journal of Economic Perspectives, Winter, 5(1), 97 - 112. https://doi.org/10.1257/jep.5.1.97

North, D. C. (1997a). Cliometrics - 40 Years Latter. American Economic Review, Papers and Proceedings, May, 87(2),

$12-14$.

North, D. C. (1997b). The Contribution of the New Institutional Economics to an Understanding of the Transition Problem. UNU/WIDER Annual Lecture.

North, D. C. (1999a). Response to Geddes and Keohane. In Alt, J., Levi, M., \& Ostrom, E. (1999). Competition and Cooperation: Conversations with Nobelists about Economics and Political Science. New York: Russell Sage Foundation, pp. 247 - 252.

North, D. C. (1999b). In Anticipation of the Marriage of Political and Economic Theory. In Alt, J., Levi, M., \& Ostrom, E. (1999). Competition and Cooperation: Conversations with Nobelists about Economics and Political Science. New York: Russell Sage Foundation, pp. 314-317

North, D. C. (2003). Institutions, Institutional Change and Economic Performance, Masmedia, Zagreb.

North, DC (1990). Institutions, Institutional Change and Economic Performance, $18^{\text {th }}$ edition, Cambridge University Press, SAD.

North, DC (1994). Institutions and Economic Theory. The American Economist, 36 (1), $3-6$.

Ott, K. (2004). Croatian accession to the European union: Institutional challenges. Zagreb, Institut za javne financije: Zaklada Friedrich Ebert.

Pieper, U. (2000). Deindustrialization and the Social and Economic Sustainability Nexus in Developing Countries: Cross-Country Evidence on Productivity and Employment. Journal of Development Studies, Taylor \& Francis Journals, 36(4), 66-99. https://doi.org/10.1080/00220380008422638

Rodrik, D. (1997). TFPG Controversies, Institutions, and Economic Performance in East Asia. National Bureau of Economic Research Working Paper, No. 5914.

Rodrik, D. (2010). One Economics, Many Recipes: Globalization, Institutions and Economic Growth, Princeton: UP Princeton.

Rodrik, D., Subramanian, A. \& Trebbi, F. (2002). Institutions Rule: the primacy of institutions over integration and geography in economic development. IMF Working Paper, No. 02/189

Shleifer, A. (1997). Government in transition. European Economic Review, 41, 385-410.

Start-up Service Austria, www.gruenderservice.at

Statistik Austria: http://www.statistik.at/web_en/statistics/------/hows_austria/index.html, pp. 23

Sun, J., Ji, Z., Chen, W., \& Wang, X. (2020). State ownership, institutional development, and corporate philanthropic giving: an integrated view of legitimacy-efficiency trade-offs, Economic Research-Ekonomska Istraživanja, https://doi.org/10.1080/1331677X.2020.1802322

The Austrian Federal Economic Chamber, http://wko.at

The Central Bank of Bosnia and Herzegovina: www.cbbh.ba

The Central Registration and Information on Economic Activity of the Republic of Poland, https://prod.ceidg.gov.pl 


\section{ENTREPRENEURSHIP AND SUSTAINABILITY ISSUES}

ISSN 2345-0282 (online) http://jssidoi.org/jesi/

2021 Volume 8 Number 3 (March)

http://doi.org/10.9770/jesi.2021.8.3(32)

The Croatian National Tourist Board, http://business.croatia.hr/hr-HR/Hrvatska-turisticka-zajednica

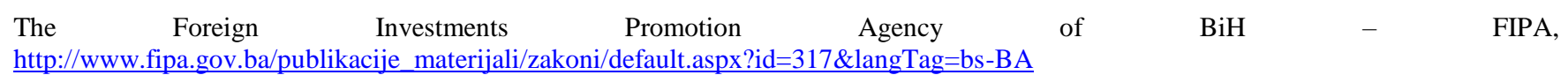
http://www.fipa.gov.ba/publikacije_materijali/zakoni/default.aspx?id=317\&langTag=bs-BA

The Growth Report: Strategies for Sustained Growth and Inclusive Development (2018), The International Bank for Reconstruction and Development / The World Bank, The Commission on Growth and Development.

The Statistics Agency of Bosnia and Herzegovina, The Central Bank of Bosnia and Herzegovina http://www.bhas.ba/Home/

The Ministry of Finance of the Republic of Croatia, https://mfin.gov.hr/

Trofimov, I. D. (2017). Entrepreneurship and Policy Dynamics: a Theoretical Framework. Journal of Eurasian Economic Dialogue, 2(3), $13-29$.

Vasconcelos, V.V. (2021). Social justice and sustainable regional development: reflections on discourse and practice in public policies and public budget. Insights into Regional Development, 3(1), 10-28. https://doi.org/10.9770/IRD.2021.3.1(1)

Why Institutions Matter Dr. Douglass C. North (1993). Nobel Memorial Prize in Economics, https://www.youtube.com/watch?v=8d$\underline{\text { O7T0p3zE\&list=PLDFB3E6119CF6D491\&index }=2}$

Wu, J., Ma, Z., Liu, Z., \& Lei, C. K. (2019). A contingent view of institutional environment, firm capability, and innovation performance of emerging multinational enterprises. Industrial Marketing Management, 82, 148-157, https://doi.org/10.1016/j.indmarman.2019.01.018

Xu, K., Hitt, M.A., Brock, D., Pisano, V., Huang, L.S.R. (2021). Country institutional environments and international strategy: A review and analysis of the research, Journal of International Management, 27(1).

Yongjian, L., Ning, Y., Xiaofang, D. (2005). A Study on the Relationship between Institutions and Economic Growth - The Case of Ningbo $H i$-Tech Park. Master Dissertations. Kristianstad University. 


\section{ENTREPRENEURSHIP AND SUSTAINABILITY ISSUES}

ISSN 2345-0282 (online) http://jssidoi.org/jesi/

2021 Volume 8 Number 3 (March)

http://doi.org/10.9770/jesi.2021.8.3(32)

Marinko ŠKARE is a Full Professor in economics and Editor in Chief of Taylor \& Francis Group (Routledge) journal Economic Research - Ekonomska istraživanja at the Faculty of Economics and Tourism "Dr. Mijo Mirković", Juraj Dobrila University of Pula, where he is also the Vice-Rector for Research and Arts. His scientific interests include poverty, growth, golden triangle, chaos economics, economic philosophy, general economics, economic history.

ORCID ID: 0000-0001-6426-3692

Sanja RADOLOVIĆ holds a Ph.D. in Economics and has an MBA degree. She gives lectures on Human resources management and the Basics of entrepreneurship. As the Head of Research and Project Office at the Juraj Dobrila University of Pula, her expertise includes project management, strategic planning, and institutional development.

ORCID ID: 0000-0001-5867-1083

Manuela TVARONAVIČIENÉ is Full Professor at Vilnius Gediminas Technical University (Vilnius Tech) and General Jonas Zemaitis Military Academy of Lithuania. She expert of European Comission and national head of international projects, financed by European Union and Norway (Framework 7, Horizon 2020, Baltic Research Programm),

ORCID ID: orcid.org/0000-0002-9667-3730

Make your research more visible, join the Twitter account of ENTREPRENEURSHIP AND SUSTAINABILITY ISSUES: @Entrepr69728810

Copyright (C) 2021 by author(s) and VsI Entrepreneurship and Sustainability Center

This work is licensed under the Creative Commons Attribution International License (CC BY).

http://creativecommons.org/licenses/by/4.0/

CC) (i) Open Access 